\title{
Proxapertites from Walat Formation, Sukabumi, West Java, Indonesia.
}

\author{
Rizki Satria Rachman ${ }^{1^{*}}$, Winantris ${ }^{1}$, Budi Muljana ${ }^{1}$ \\ ${ }^{1}$ Departmenr of Geology, Universitas Padjadjaran, Sumedang, West Java 45363, Indonesia.
}

\author{
* Corresponding author : rizkisatriarachman@gmail.com \\ Tel.: +62-81-223-668-317 \\ Received: Nov 12, 2020; Accepted: March 15, 2021. \\ DOI 10.25299/jgeet.2021.6.1.5583
}

\begin{abstract}
Proxapertites have become one of the most significant indicators of ancient rock in Indonesia. Walat Formation is one of the oldest rocks exposed in Sukabumi, West Java, Indonesia. These Proxapertites have not been described in detail about their characteristics in previous studies, especially on Walat Formation. Therefore, knowing the characteristics of Proxapertites becomes interesting, especially in Walat Formation, which can be a reference for the characteristics of the late Eocene Proxapertites (37.8 - 33.9 million) in Indonesia. Acetolysis method was carried out for the preparation of pollen and spores; description and determination were carried out to see the characteristics of Proxapertites that present in Walat Formation. Result, there are three types of Proxapertites. Proxapertites operculatus have sizes $23-86 \mu$ with average 40.5 (P) and 51.1 (E) $\mu$, index PE 0,43 - 1, Peroblate - Subspheroidal - Oblate Spheroidal, Fine-Reticulate ornamentation, and Asymmetric Monosulcate aperture. Proxapertites cursus have sizes $23-86 \mu$ with average 39.8 (P) and 49.8 (E) $\mu$, index PE 0.51 - 1, Oblate - Subspheroidal - Oblate Spheroidal, Reticulate ornamentation, and Asymmetric Monosulcate aperture. Whereas Proxapertites psilatus have sizes 29 - $75 \mu$ with average 42.3 (P) and 52.5 (E) $\mu$, index PE 0.58 - 1, Oblate - Subspheroidal - Oblate Spheroidal, Psilate ornamentation, and Asymmetric Monosulcate aperture. These three Proxapertites can be distinguished by their type of ornamentation. Meanwhile, other aspects have similar characteristics and are affected by the appearance of individual pollen on the slide during preparation.
\end{abstract}

Keywords: Proxapertites, Characteristics, Walat Formation, and Sukabumi

\section{Introduction}

Indonesia is a tropical climate country that has a very high diversity of fauna (Stuijts, 1993). The wealth of this fauna has continued to increase since the last ice age in the Pleistocene (Stuijts, Newsome and Flenley, 1988; Kaars and Dam, 1997; Kaars et al., 2001; Hartmann et al., 2013). During ice age, montane forest plants dominated and extended to the northern region of Australia and Indonesia, while during the Holocene the vegetation from the Lowland Forest extended again, indicating a warmer and humid climate. (Hope and Tulip, 1994; Kaars et al., 2000). However, the richness of this fauna is affected by human activities that tend to damage the ecosystem in an area in Holocene (Smiet, 1992; Kaars and Bergh, 2004). In general, the vegetation on the surface will produce pollen and spores as an effort to reproduce these plants. Many pollens and spores that are distributed will fall to the ground and are preserved as fossils in the rock (Gray and Boucot, 1975; Hall, 1981; Retallack, 1984; Refsnider et al., 2014). Pollen and spores are preserved in soil and rock, which shows the condition of vegetation at time the pollen and spores are deposited (Clapperton et al., 1989; Vermoere et al., 1999; Puspitasari, Suedy and Haryanti, 2018). In the forest areas, the pollen produced will come from tall trees such as canopy tree species, while non-forest areas that tend to be open have pollen from ferns and grasses. (Stuijts, 1993).

Walat Formation is one of the rock formations in the Bogor Basin, which has preservation of pollens and spores or is known as palynomorphs (Kusumahbrata, 1994). Walat Formation is the upper part of Bayah Formation which is one of the oldest rocks in West Java exposed in the Sukabumi area (Martodjojo, 2003; Sunardi and Adhiperdana, 2013) (Fig. 1). Walat Formation has rocks with a range of Eocene - Oligocene ages with a predominant age tendency in the late Eocene $(37.8-33.9 \mathrm{Ma})$ with rocks deposited in a fluvial environment. (Effendi, Kusnama and Hermanto, 1998; Martodjojo, 2003; Sunardi and Adhiperdana, 2013; Wibowo and Kapid, 2014). Pollen and spores in this formation are found to be very well preserved, particularly in the coal. Pollen and spores in Walat Formation are very diverse, but Proxapertites are fascinating plant fossils (pollen) because they are important palynomorph for rocks that have ancient age in Indonesia (Zetter, Hesse and Frosch-Radivo, 2001; Lelono, 2007b, 2007c, 2007a; Lelono and Morley, 2011). 


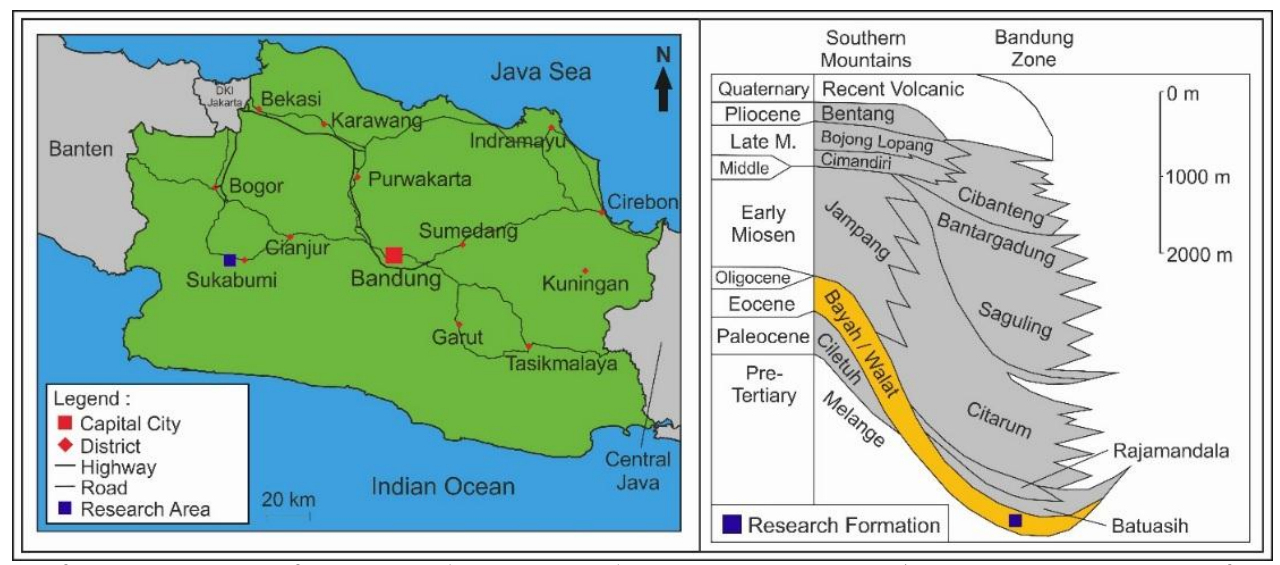

Fig. 1. Location of research area; Left, Research location in relation to West Java, Indonesia; Right, Location of rock formations to all Formations in southern part of Bogor Basin (Modified from Martodjojo, 2003)

Research in Indonesia has been mostly carried out on age and environmental range of Proxapertites, where the Proxapertites have Paleocene - Eocene age range (66 - 33.9 million) and grow in areas around rivers which are called fluvial (Hammen, 1956; Rull, 1999; Zetter, Hesse and Frosch-Radivo, 2001; Hesse and Zetter, 2007). However, the previous researchers have not been described the description of the Proxapertites. Therefore, knowing the characteristics of Proxapertites is interesting to be able to become a reference for how Proxapertites characteristics in the late Eocene age (37.8 - 33.9 Ma) in Indonesia. This research is located in the quartz sandstone mine in Sukadamai Village, Sukabumi Regency, West Java.

\section{Method}

The research was carried out in several stages, started from fieldwork, pollen and spores preparation, and laboratory analysis. Fieldwork was carried out using the measured section method to obtain the stratigraphic lithology sequence of the rocks. After that, the samples were taken at particular intervals in the Walat Formation rocks (Fauzi, 2017; Tania, 2019). Furthermore, the samples were prepared using the acid treatment method to separate the pollen and spores from other impurities (Fig. 2). The acid treatment method was carried out by immersing rock samples with various chemicals, both $\mathrm{HF}, \mathrm{HCl}, \mathrm{KOH}$, alcohol, and $\mathrm{HNO}_{3}$ (Setijadi and Suedi, 2011; Feagri and Iversen in Lestari, 2018).

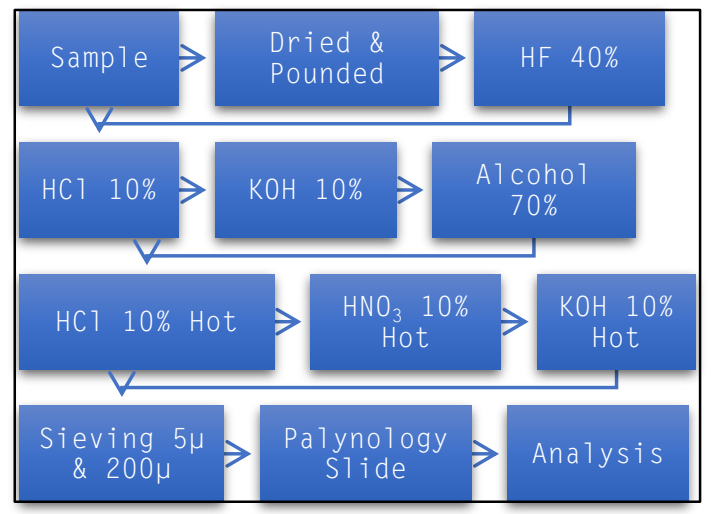

Fig. 2 The acid treatment method for palynological analysis (Modified from Setijadi and Suedi, 2011; Feagri and Iversen in Lestari, 2018)
Laboratory analysis was carried out to identify the presence of fossil pollen and spores in the sample. Then, the pollen and spores slide preparations are described, identified, and determined to see how changes in the content of pollen and spores, especially Proxapertites species in Walat Formation. The pollen and spore descriptions include size, shape (index PE), ornamentation, and aperture (Reitsma, 1970; Noraini et al., 2017). Identification and determination were carried out using the Olympus CX-22 binocular microscope (Sarah, Suedy and Hastuti, 2017). After the Proxapertites were identified, detailed description with basic mathematical analysis was carried out to see how the morphology of Proxapertites in Walat Formation at the late Eocene age.

\section{Result}

This research is located at $06^{\circ} 56^{\prime} 28.83^{\prime \prime} \mathrm{S}$ $06^{\circ} 56^{\prime} 51.52^{\prime \prime} \mathrm{S}$ and $106^{\circ} 51^{\prime} 12.96^{\prime \prime} \mathrm{E}-106^{\circ} 50^{\prime} 57.93^{\prime \prime} \mathrm{E}$ in Quartz Sandstone mine, Sukadamai Village, which is an area where part of the Walat Formation is exposed. The rocks found in this Formation are claystone, quartz sandstones, quartz conglomerates, and coals as an insert in some parts of this Formation (Fig. 3). In general, claystone, sandstone, and coal have an older position stratigraphically in the northern part of the research study (Zone 1). Meanwhile, sandstones and conglomerates are found in a younger stratigraphic position in the southern part of the research area (Zone 2).

The rock characteristics found in this study are stratigraphically varied. In zone 1 , the sandstones are found to have very fine - medium sand grain-size with yellow - gray colors accompanied by sedimentary structure in the form of graded bedding towards claystone and coal. Claystone was found to have gray colors and clay grain-size with parallel lamination sedimentary structures found in several parts. Finally, coal has black colors and clay grain-size, including a large amount of organic material left over from past plant remains. In zone 2, massive yellow sandstones were found to have medium sand grain-sized. While the conglomerates in this zone have granule - pebble grain-size with a graded bedding structure. 


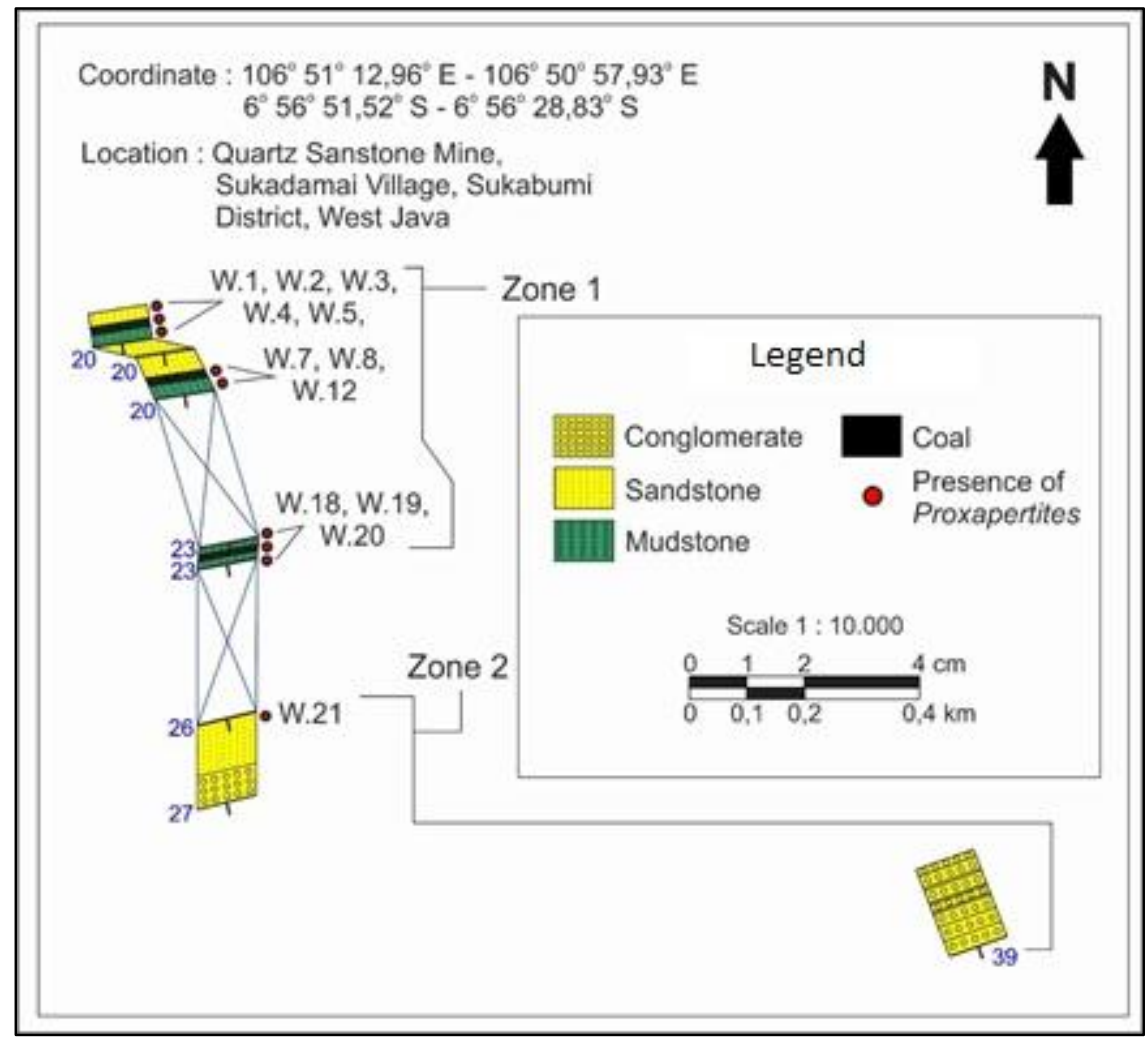

Fig. 3. The research track shows the lithology and the presence of proxapertites in the research area

32 rock samples prepared to see the content of pollen and spores. 12 samples from all prepared samples had the presence of Proxapertites pollen in the Walat Formation rocks (Fig. 3). Proxapertites present in Walat Formation were identified from 3 main types, namely Proxapertites operculatus, Proxapertites psilatus, and Proxapertites cursus. At least 835

individual Proxapertites consisted of 676 fossils of Proxapertites operculatus, 48 fossils of Proxapertites psilatus, and 111 fossils of Proxapertites cursus. All of the Proxapertites were randomly distributed within the rock sample from the oldest position to the younger stratigraphically (Fig. 4).

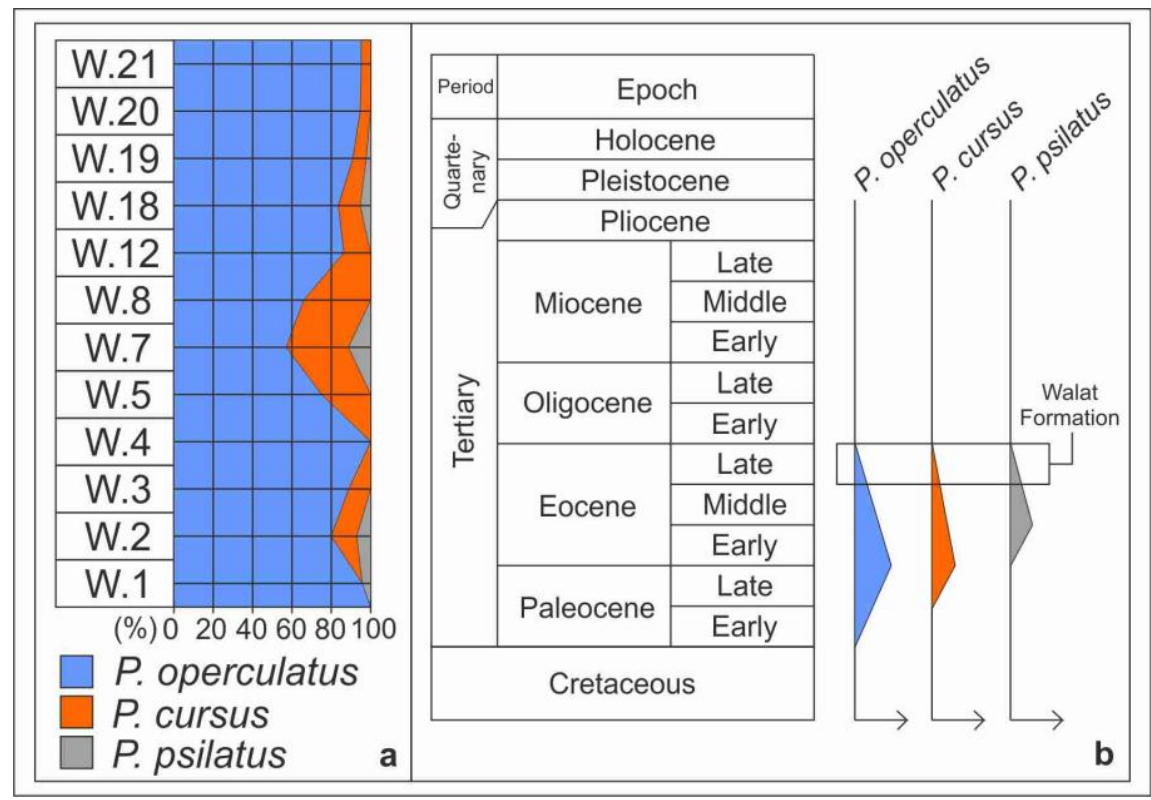

Fig. 4. Proxapertites in the study sample; a. Comparison of the number of Proxapertites operculatus, Proxapertites psilatus, and Proxapertites cursus, b. The age range of Proxapertites in previous studies was associated with the Walat Formation (Edet and Nyong, 1994; Umeji, 2003)

From this figure, it can be seen that there is no significant change in the presence of the three types of Proxapertites in the study area. Changes can only be seen that the Proxapertites cursus is increasingly developing in the middle of Walat Formation (Fig. 4). The presence of Proxapertites in Walat Formation 
should not have undergone significant changes considering that these three types of Proxapertites are indeed present in Eocene age rocks and have not experienced either extinction or emergence of these three types of Proxapertites (Rull, 1999; Zetter, Hesse and Frosch-Radivo, 2001; Lelono, 2007b, 2007c, 2007a; Lelono and Morley, 2011).

\section{Discussion}

In Fig. 4, Proxapertites operculatus is more dominant when compared to Proxapertites psilatus and Proxapertites cursus. The dominance of Proxapertites operculatus in Walat Formation can be explained from previous studies. Essentially $P$. operculatus was present earlier than $P$. cursus and $P$. psilatus. P. operculatus was present in the Cretaceous Early Paleocene range, $P$. psilatus was present in the Early Eocene, whereas $P$. cursus was present in Indonesia at the Late Paleocene age. These three Proxapertites continued to grow until they reached their peak at Paleocene - Eocene boundary age and then decreased to become extinct in Late Eocene. Accordingly, it can be seen that the $P$. operculatus development time was longer than that of $P$. cursus and $P$. psilatus, so that $P$. operculatus was more dominant in Late Eocene before these three Proxapertites became extinct (Fig. 4b). Proxapertites psilatus in this study is an initial finding of the presence of $P$. psilatus in Indonesia. The previous studies have not identified the presence of $P$. psilatus yet, because there was very little difference between Proxapertites operculatus and Proxapertites psilatus. Therefore, several studies have identified Proxapertites psilatus to be Proxapertites operculatus.
Based on the types found in this research, the characteristics of Proxapertites that present in the Walat Formation are divided into 3 (Fig. 5). Proxapertites operculatus has an individual size of 23 $86 \mu$, according to Reitsma (1970), included in small large category with an average size 40.5 (P); 51.1 (E). Index PE of $P$. operculatus ranges from $0.43-1$. Therefore, this form of Proxapertites operculatus has Peroblate - Subspheroidal - Oblate Spheroidal type. Moreover, $P$. operculatus has ornamentation displaying fine-webs, which are called Fine-Reticulate. Proxapertites operculatus has one aperture, and it is located randomly on the individual surface of the fossil, and also has an irregular width. Therefore, the aperture type is Asymmetric Monosulcate. Proxapertites cursus has an individual size of $23-86 \mu$, according to Reitsma (1970), included in small - large category with an average size $39.8(\mathrm{P}) ; 49.8(\mathrm{E})$ and index PE ranges from 0.51 - 1. Therefore, this form of Proxapertites cursus has Oblate - Subspheroidal - Oblate Spheroidal type. This $P$. cursus has rougher overall ornamentation compared to $P$. operculatus, so it has Reticulate ornamentation type, but $P$. cursus has the same aperture as $P$. operculatus, namely Asymmetric Monosulcate. Last, $P$. psilatus has pollen size ranging from $29-75 \mu$ which included in small - large category (Reitsma, 1970) with an average size 42.3 (P); 52.5 (E) and index PE ranges from 0.58 - 1, classified as Oblate Subspheroidal - Oblate Spheroidal. Moreover, $P$. psilatus has a very fine ornamentation called Psilate ornamentation with same aperture as $P$. operculatus and $P$. cursus, namely Asymmetric Monosulcate.

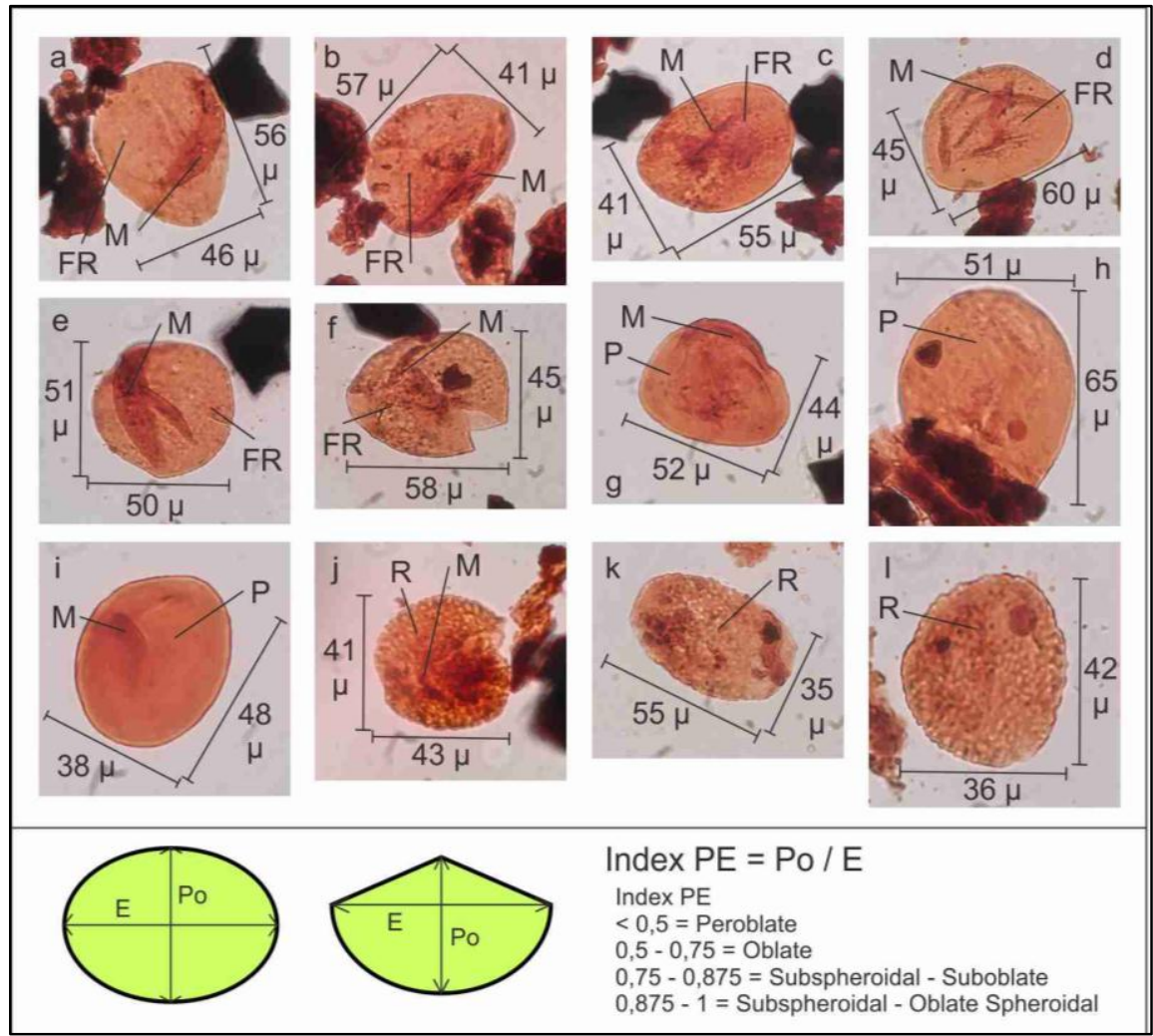

Fig. 5. Proxapertites of Study Area; a - f. Proxapertites operculatus; g - i. Proxapertites psilatus; j - l. Proxapertites cursus; P. Psilate; FR. Fine-Reticulate; R. Reticulate; M. Monosulcate; E. Ekuatorial axis; Po. Polar axis 
In general, Proxapertites operculatus, Proxapertites psilatus, and Proxapertites cursus are examined from the size and index PE produced by these three types of Proxapertites showed no difference at all (Fig. 6). When observed from the polar axis, $P$. operculatus, $P$. psilatus, and $P$. cursus have almost the same individual size, the peak of individual dominance size for these three Proxapertites species are in the range of 30-50 $\mu$. When observed from its equatorial axis, $P$. operculatus, $P$. psilatus, and $P$. cursus have the same individual size again. The dominance peak of these three types of Proxapertites is in the range of 40 - $60 \mu$. On the other hand, on this equatorial axis $P$. cursus had a slightly smaller tendency than $P$. operculatus and $P$. psilatus. This is indicated by the $P$. cursus line in Fig. 6b, which has a higher predominance of size $40-50 \mu$ than $P$. operculatus and $P$. psilatus is balanced between sizes $40-50 \mu$ and $50-60 \mu$.

Index PE of the three types of Proxapertitesare very similar. Only a few or none of them have peroblate index PE. Whereas for other forms of index PE (Oblate,
Subspheroidal - Suboblate, and Subspheroidal - Oblate Spheroidal) has uniform distribution in the range of 30$40 \%$, but tend to show that P. psilatus has index PE of the Subspheroidal - Suboblate type with a total of 50\%.

Statistically, comparative test using MannWhitney Test was carried out to see the significance of differences in the polar axis, equatorial axis, and index PE. Result, the polar axis obtained a significance of 0.17 (Operculatus \& Psilatus), 0.09 (Cursus \& Psilatus), and 0.42 (Operculatus \& Cursus). For the equatorial axis, the significance was 0.37 (Operculatus \& Psilatus), 0.11 (Cursus \& Psilatus), and 0.13 (Operculatus \& Cursus). Last, the index PE obtained a significance of 0.64 (Operculatus \& Psilatus), 0.87 (Cursus \& Psilatus), and 0.57 (Operculatus \& Cursus). The overall statistical results have a value greater than 0.05 ( $5 \%$ error rate and 95\% confidence level). Therefore, it can be concluded that $P$. operculatus, $P$. psilatus and $P$. cursus do not have significant difference either seen from the polar axis, equatorial axis, and index PE.

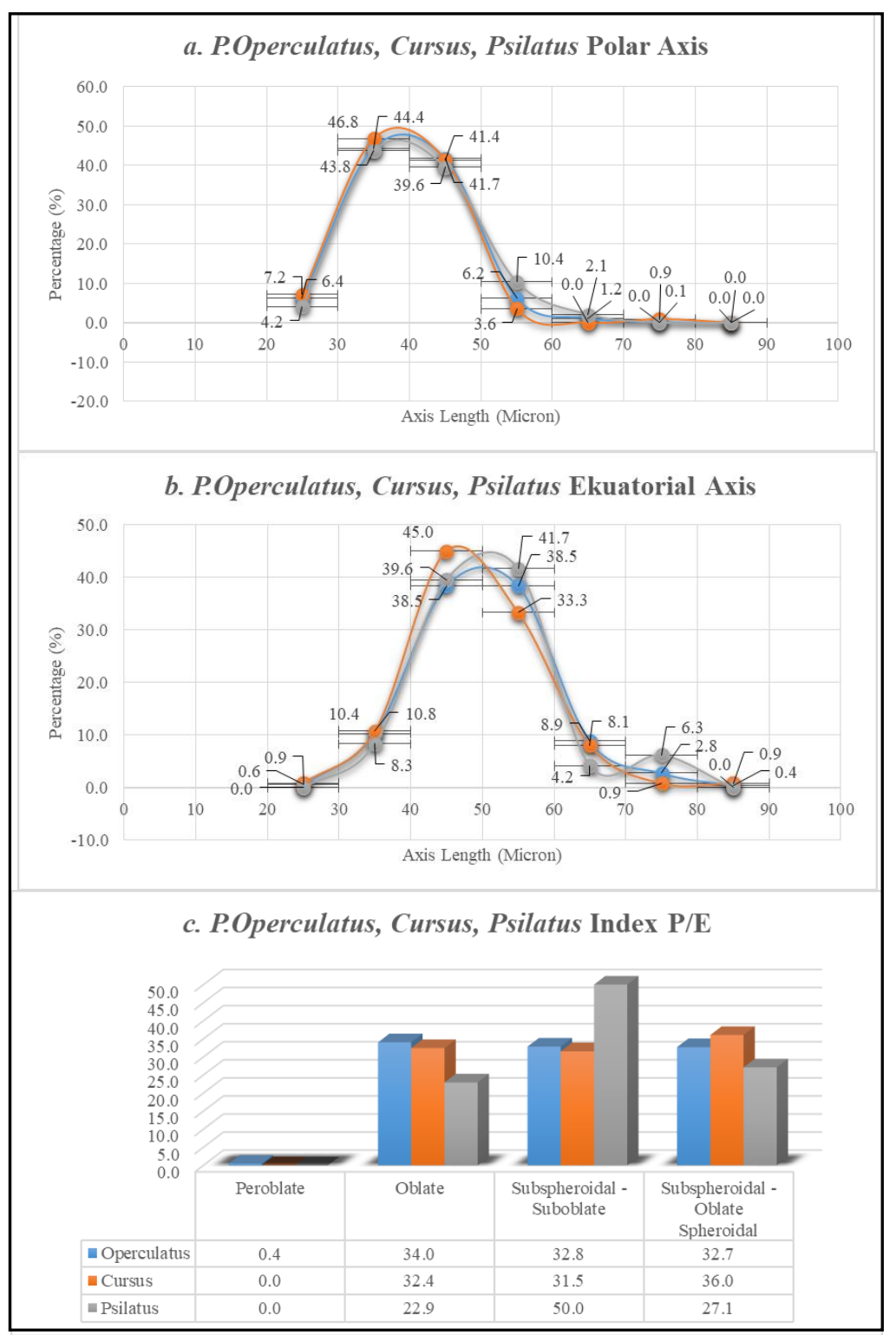

Fig. 6. Characteristics of $P$. operculatus, $P$. cursus, and $P$. psilatus; a. Polar axis comparison of $P$. operculatus, $P$. cursus, and $P$. psilatus; b. Equatorial axis comparison of P. operculatus, P. cursus, and P. psilatus; c. Comparison of the Proxapertites Index PE 
Until now, the size and index PE of pollen and spores have become the basis for identifying some pollen and spores present in a sample (Reitsma, 1970). If we look further, the index PE is obtained from the calculation of the length of the polar and equatorial axis individual pollen and spores, but the directions of individual pollen and spores in the preparation cannot be determined. It indicated that index PE produced depends on the appearance of pollen and spores obtained from the results of preparation. If it is found that the pollen and spores in an individual have an oblique appearance, it can be ascertained that index PE will have small value due to far difference in measured axis length, both polar and equatorial. Therefore, index PE basically cannot be used as a basis for identifying pollen and spores due to the results are dependent on the individual appearance. Index PE can be the basis if pollen and spores can be seen in 3 dimensions, so that index PE is calculated based on the correct polar and equatorial axis of an individual pollen and spores.

These three Proxapertites have Asymmetric Monosulcate aperture type. Similar to the index PE, this aperture is also influenced by appearance direction of individual pollen and spores, so that not all identified pollen and spores individuals have an Asymmetric Monosulcate aperture appearance. $P$. operculatus aperture was identified in $44 \%$ of individuals, while $56 \%$ $P$. operculatus were not at position where the aperture was visible. For P. cursus, the aperture was identified in $39 \%$ of pollen individuals while the rest did not show the presence of the Asymmetric Monosulcate aperture. $P$. psilatus, aperture asymmetric monosulcate was seen in $58 \%$ of all identified individuals. Therefore, the pollen and spores position on the preparation is greatly influenced the aperture appearance of the individual pollen and spores, where the identification of aperture will affect the identification of the pollen and spores in a sample.

Compared to the previous studies, several studies stated that Proxapertites has a size range between 20 $70 \mu$ with the predominance being in $40-60 \mu$. Also, these three Proxapertites are oval to perfectly round in shape with Psilate ornamentation in $P$. psilatus species, Fine-Reticulate in $P$. operculatus, and Reticulate in $P$. cursus with Asymmetric Monosulcate aperture type (Germeraad, Hoping and Muller, 1968; Singh and Tripathi, 1986; Harley and Baker, 2001; Zetter, Hesse and Frosch-Radivo, 2001; Hesse and Zetter, 2007; Trujillo and Roche, 2009; Huang et al., 2020). So it can be said that Proxapertites in this study have similar characteristics with Proxapertites in previous studies. This is indicated by the same size range (20 - $70 \mu$ versus $23-86 \mu$ ) with a predominance of the size (40 $60 \mu$ ) shown in Fig. 6. The similarities are also shown from the aperture and ornamentation.

Table 1. Description Proxapertites operculatus, Proxapertites psilatus, and Proxapertites cursus

\begin{tabular}{|c|c|c|c|c|c|c|}
\hline Proxapertites & Size $(\mu)$ & Average $(\mu)$ & $\begin{array}{l}\text { Index } \\
\text { PE }\end{array}$ & Shape & Ornamentation & Aperture \\
\hline P. Operculatus & $\begin{array}{c}23-86 \\
\text { (Small - } \\
\text { Large) }\end{array}$ & $\begin{array}{l}40.5(\mathrm{P}) \\
51.1(\mathrm{E})\end{array}$ & $0.43-1$ & $\begin{array}{c}\text { Peroblate - } \\
\text { Subspheroidal - Oblate } \\
\text { Spheroidal }\end{array}$ & Fine Reticulate & $\begin{array}{l}\text { Asymmetric } \\
\text { Monosulcate }\end{array}$ \\
\hline P. Cursus & $\begin{array}{c}23-86 \\
\text { (Small - } \\
\text { Large) }\end{array}$ & $\begin{array}{c}39.8(\mathrm{P}) \\
49.8(\mathrm{E})\end{array}$ & $0.51-1$ & $\begin{array}{l}\text { Oblate - } \\
\text { Subspheroidal - Oblate } \\
\text { Spheroidal }\end{array}$ & Reticulate & $\begin{array}{l}\text { Asymmetric } \\
\text { Monosulcate }\end{array}$ \\
\hline P. Psilatus & $\begin{array}{c}29-75 \\
\text { (Small - } \\
\text { Large) }\end{array}$ & $\begin{array}{c}42.3(\mathrm{P}) \\
52.5(\mathrm{E})\end{array}$ & $0.58-1$ & $\begin{array}{l}\text { Oblate - } \\
\text { Subspheroidal - Oblate } \\
\text { Spheroidal }\end{array}$ & Psilate & $\begin{array}{l}\text { Asymmetric } \\
\text { Monosulcate }\end{array}$ \\
\hline
\end{tabular}

These three Proxapertites identified in this research prevail some similarities and differences characteristics of the individual pollen and spores (Table 1). Proxapertites are both operculatus, psilatus, and cursus had no significant difference in size and index PE. Moreover, the aperture of these three types of Proxapertites has the same type, namely Asymmetric Monosulcate. The only fundamental difference between these three Proxapertites can only be seen from the surface ornamentation of individual pollen. $P$. operculatus has fine-web ornamentation type (FineReticulate), $P$. psilatus has very fine ornamentation type (Psilate), while $P$. cursus has coarser-web ornamentation type (Reticulate).

\section{Conclusion}

Walat Formation contains Proxapertites divided into three types, namely Proxapertites operculatus, Proxapertites psilatus, and Proxapertites cursus. Proxapertites operculatus has size 23 - $86 \mu$ (small large), average 40.5 (P); 51.1 (E), index PE 0.43 - 1, Peroblate - Subspheroidal - Oblate Spheroidal, Fine-
Reticulate ornamentation, and Asymmetric Monosulcate Aperture. Proxapertites psilatus has size 29 - $75 \mu$ (small - large), average 42.3 (P); 52.5 (E), index PE 0.58 - 1, Oblate - Subspheroidal - Oblate Spheroidal, Psilate ornamentation, and Asymmetric Monosulcate Aperture. While Proxapertites cursus has size 23 - $86 \mu$ (small - large), average 39.8 (P); 49.8 (E), index PE 0.51 - 1, Oblate - Subspheroidal - Oblate Spheroidal, Reticulate ornamentation, and Asymmetric Monosulcate Aperture.

The three Proxapertites can be distinguished by their type of ornamentation. This occurs because other aspects have similar characteristics and are affected by the appearance of individual pollen in the slide during preparation.

\section{Acknowledgements}

Thank you to the Chancellor of Padjadjaran University for funding research through the HIU-RKDU program, Paleontology laboratory team of the Faculty of Geological Engineering UNPAD, and all parties who 
have helped and provided encouragement in this research.

\section{References}

Clapperton, C.M. et al., 1989. Late-glacial and Holocene Glacier Fluctuations and Environmental Change on South Georgia, Southern Ocean. Quaternary Research 31(2), 210-228. doi:10.1016/00335894(89)90006-9

Edet, J.J., Nyong, E.E., 1994. Palynostratigraphy of Nkporo Shale exposures (late CampanianMaastrichtian) on the Calabar Flank, SE Nigeria. Review of Palaeobotany and Palynology 80(1-2), 131-147. doi:10.1016/0034-6667(94)90098-1

Effendi, A.C., Kusnama, Hermanto, B., 1998. Peta Geologi Lembar Bogor, Jawa Barat, Skala 1: 100.000.

Fauzi, R., 2017. Studi Lingkungan Pengendapan Formasi Balikpapan Daerah Batu Besaung, in Prosiding Seminar Nasional Teknologi, Inovasi dan Aplikasi di Lingkungan Tropis IV. Samarinda: Universitas Mulawarman, 76-80.

Germeraad, J., Hoping, C.A., Muller, J., 1968. Palynology of Tertiary Sediments From Tropical Areas. Review of Palaeobotany and Palynology 6(3-4), 189-348. doi:10.1016/0034-6667(68)90051-1

Gray, J., Boucot, A.J., 1975. Color Changes in Pollen and Spores: A Review. Geological Society of America Bulletin 86(7), 1019-1033. doi:10.1130/00167606(1975)86<1019:CCIPAS>2.0.CO;2

Hall, S.A., 1981. Deteriorated Pollen Grains and The Interpretation of Quaternary Pollen Diagrams. Review of Palaeobotany and Palynology 32(2-3), 193-206. doi:10.1016/0034-6667(81)90003-8

Hammen, T.V.D., 1956. Description of Dome Genera and Species of Fossil Pollen and Spores. Boletín Geológico 4(2-3), 111-117.

Harley, M.M., Baker, W.J., 2001. Pollen aperture morphology in Arecaceae: Application within phylogenetic analyses, and a summary of record of the fossil record of palm-like pollen. Grana 40(1-2), $45-77$. doi:10.1080/00173130152591877

Hartmann, A. et al., 2013. Multi-proxy Evidence for Human-induced Deforestation and Cultivation from a Late Holocene Stalagmite from middle java, Indonesia. Chemical Geology 357, 8-17. doi:10.1016/j.chemgeo.2013.08.026

Hesse, M., Zetter, R., 2007. The fossil pollen record of Araceae. Plant Systematics and Evolution 263(12), 93-115. doi:10.1007/s00606-006-0468-z

Hope, G., Tulip, J., 1994. A long vegetation history from lowland Irian Jaya, Indonesia. Palaeogeography, Palaeoclimatology, Palaeoecology 109(2-4), 385-398. doi:10.1016/0031-0182(94)90187-2

Huang, H. et al., 2020. Eocene palms from central Myanmar in a South East Asian and global perspective: Evidence from the palynological record. Botanical Journal of the Linnean Society 194(2), 177-206. doi:10.1093/botlinnean/boaa038

Kaars, S.V.D. et al., 2000. A Late Quaternary palaeoecological record from the Banda Sea,
Indonesia: Patterns of vegetation, climate and biomass burning in Indonesia and northern Australia. Palaeogeography, Palaeoclimatology, Palaeoecology 155(1-2), 135-153. doi:10.1016/S0031-0182(99)00098-X

Kaars, S.V.D. et al., 2001. Late Quaternary Palaeoecology, Palynology and Palaeolimnology of a Tropical Lowland Swamp: Rawa Danau, West-Java, Indonesia. Palaeogeography, Palaeoclimatology, Palaeoecology 171(3-4), 185-212. doi:10.1016/S0031-0182(01)00245-0

Kaars, S.V.D., Bergh, G.D.V.D., 2004. Anthropogenic Changes in the Landscape of West Java (Indonesia) During Historic Times, Inferred From a Sediment and Pollen Record From Teluk Banten. Journal of Quaternary Science 19(3), 229-239. doi:10.1002/jqs.804

Kaars, S.V.D., Dam, R., 1997. Vegetation and Climate Change in West-Java, Indonesia During The Last 135,000 Years. Quaternary International 37, 6771. doi:10.1016/1040-6182(96)00002-X

Kusumahbrata, Y., 1994. Sedimentology and Stratigraphy of the Bayah, Walat and Ciletuh Formations, Southwest Java Basin, Indonesia. University of Wollongong Dissertation. University of Wollongong.

Lelono, E.B., 2007a. Gondwanan Palynomorphs From The Paleogene Sediments of East Java: The Evidence Of Earlier Arrival. Lemigas Scientific Contributions 30(2), 1-12.

Lelono, E.B., 2007b. Palinomorf Eosen dari Selat Makasar. Lembaran Publikasi Lemigas 41(2), 110.

Lelono, E.B. 2007c. Zonasi Polen Tersier Indonesia Timur. Lembaran Publikasi Lemigas 41(1), 1-8.

Lelono, E.B., Morley, R.J., 2011. Oligocene palynological succession from the East Java Sea. Geological Society of London Special Publication 355(1), 333-345. doi:10.1144/SP355.17

Lestari, T.H., 2018. Rekonstruksi Vegetasi Pasca Kebakaran Di Blok Gunung Geulis, Suaka Margasatwa Cikepuh Berdasarkan Bukti-Bukti Palinologi. Jurnal Geologi dan Sumberdaya Mineral 19(2), 107-116.

Martodjojo, S., 2003. Evolusi Cekungan Bogor Jawa Barat. Bandung: Institut Teknologi Bandung.

Noraini, T. et al., 2017. Ciri Morfologi Diagnosis Debunga Bruguiera, Ceriops, Kandelia dan Rhizophora (Rhizophoraceae) di Semenanjung Malaysia. Sains Malaysiana 46(12), 2291-2303. doi:10.17576/jsm-2017-4612-05

Puspitasari, R., Suedy, S.W.A., Haryanti, S., 2018. Plant diversity based on pollen and spores morphology from sediment lake of Kedung Ombo Purwodadi. NICHE Journal of Tropical Biology 1(2), 35-41. doi:10.14710/niche.1.2.3541

Refsnider, K.A. et al., 2014. Subglacially precipitated carbonates record geochemical interactions and pollen preservation at the base of the Laurentide Ice Sheet on central Baffin Island, eastern Canadian Arctic. Quaternary Research 81(1), 94105. doi:10.1016/j.yqres.2013.10.014 
Reitsma, T., 1970. Suggestions Towards Unification of Descriptive Terminology of Angiosperm Pollen Grains. Review of Palaeobotany and Palynology 10(1), 39-60. doi:10.1016/00346667(70)90021-7

Retallack, G., 1984. Completeness of the Rock and Fossil Record: Some Estimates Using Fossil Soils. Paleobiology 10(1), 59-78. doi:https://www.jstor.org/stable/2400501

Rull, V., 1999. Palaeofloristic and palaeovegetational changes across the Paleocene/Eocene boundary in northern South America. Review of Palaeobotany and Palynology 107(1-2), 83-95. doi:10.1016/S0034-6667(99)00014-7

Sarah, S., Suedy, S.W.A., Hastuti, E.D., 2017. Ciri Morfologi Polen Dan Spora Tumbuhan Dari Sedimen Rawa Jombor Klaten. Bioma 19(1), 512. doi:10.14710/bioma.19.1.5-12

Setijadi, R., Suedi, S.W.A., 2011. Keanekaragaman Flora Hutan Mangrove Di Pantai Rembang dan Semarang Berdasarkan Bukti Palinologinya. Berkala Penelitian Hayati 7A, 25-28.

Singh, S.K.M., Tripathi, H.P., 1986. Observations on some Tertiary Zonisulcate Pollen Grains. The Palaeobotanist 35(1), 48-52.

Smiet, A.C., 1992. Forest Ecology On Java: Human Impact And Vegetation Of Montane Forest. Journal of Tropical Ecology 8(2), 129-152. doi:10.1017/S026646740000626X

Stuijts, I.M., 1993. Late Pleistocene and Holocene Vegetation of West Java, Indonesia. Rotterdam: Balkema A. A. Publishers.

Stuijts, I., Newsome, J.C., Flenley, J.R., 1988. Evidence For Late Quartenary Vegetational Change In The Sumatran And Javan Highlands. Review of Palaeobotany and Palynology 55(1-3), 207-216. doi:10.1016/0034-6667(88)90086-3

Sunardi, E., Adhiperdana, B.G., 2013. Sedimentologi dan Paleohidrologi Sedimen Fluvial Oligosen
Formasi Walat, Sukabumi, Jawa Barat. Bionatura 15(1), 8-13.

Tania, D., 2019. Perkembangan Lingkungan Pengendapan Dari Formasi Sambipitu Ke Formasi Wonosari Daerah Jelok, Desa Beji, Kecamatan Patok, Kabupaten Gunungkidul, Daerah Istimewa Yogyakarta. Jurnal Teknologi Technoscientia 11(2), 193-201. doi:10.34151/technoscientia.v11i2.1252

Trujillo, A.P., Roche, E., 2009. Paleocene-Eocene Palynology and Palynofacies From Northeastern Colombia and Western Venezuela. Colombia: Universidad de Caldas.

Umeji, O.P., 2003. Palynological data from the road section at the Ogbunike Tollgate, Onitsha, southeastern Nigeria. Journal of Mining and Geology 39(2), 95-102. doi:10.4314/jmg.v39i2.18797

Vermoere, M. et al., 1999. Pollen analysis of two travertine sections in Baskoy (southwestern Turkey): Implications for environmental conditions during the early Holocene. Review of Palaeobotany and Palynology 105(1-2), 93-110. doi:10.1016/S0034-6667(98)00068-2

Wibowo, U.P., Kapid, R., 2014. Biostratigrafi Nannoplankton Daerah Rajamandala. Jurnal Geologi Sumber Daya Mineral 15(4), 185-194. doi:10.33332/jgsm.geologi.v15i4.57

Zetter, R., Hesse, M., Frosch-Radivo, A., 2001. Early Eocene Zona-aperturate pollen grains of the Proxapertites type with affinity to Araceae. Review of Palaeobotany and Palynology 117(4), 267-279. doi:10.1016/S0034-6667(01)00096-3

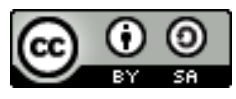

(C) 2021 Journal of Geoscience, Engineering, Environment and Technology. All rights reserved. This is an open access article distributed under the terms of the CC BY-SA License (http://creativecommons.org/licenses/by-sa/4.0/). 